\title{
Carbamyl Phosphate Synthetase and Ornithine Transcarbamylase Activities in Enzyme-Deficient Human Liver Measured by Radiochromatography and Correlated with Outcome
}

\author{
MENDEL TUCHMAN, MICHAEL Y. TSAI, ROBERT A. HOLZKNECHT, AND \\ SAUL W. BRUSILOW \\ Divisions of Metabolism and Biochemical genetics Departments of Pediatrics and Laboratory Medicine and \\ Pathology, University of Minnesota and Department of Pediatrics, Minneapolis, Minnesota 55455; and \\ Department of Pediatrics, The Johns Hopkins School of Medicine, Baltimore, Maryland 21205
}

\begin{abstract}
Sensitive and specific radiochromatographic methods to measure enzymatic activities of carbamyl phosphate synthetase I (CPS I) and ornithine transcarbamylase (OTC) were developed. The activities of these enzymes were assayed in frozen liver tissue obtained from 23 individuals with hyperammonemia caused by CPS I (five patients) and OTC deficiency (18 patients). In addition, livers of one aborted fetus with OTC deficiency and four normal individuals were studied. The assays use radioactive ornithine as a substrate followed by separation of citrulline formed in the reactions by HPLC and quantitation of the radioactivity in both aminoacids by a radioactivity flow monitor or by a scintillation counter. Both CPS I and OTC assays were linear with respect to length of incubation time and concentration of tissue homogenate. The sensitivity of the methods allowed measurements of CPS I and OTC activities as low as $0.1 \mu \mathrm{mol} / \mathrm{g} / \mathrm{min}$ on $5 \mathrm{mg}$ of liver tissue and the diagnosis of CPS I or OTC deficiency could be established on as low as 0.5 and $0.05 \mathrm{mg}$ of tissue, respectively. CPS I activity in different sections of four normal livers was $3.01 \pm 0.16 \mu \mathrm{mol} / \mathrm{g} / \mathrm{min}$ (mean $\pm \mathrm{SEM}, n=19$ ) and OTC activity was $93.4 \pm 6.3$ (mean \pm SEM, $n=19$ ). Residual enzymatic activity could be detected and measured in the liver tissues of one of the five subjects with CPS I deficiency and in 14 of 19 subjects with OTC deficiency. OTC/CPS I activity ratio in normal liver tissue was $31.2 \pm 1.3$ (mean $\pm \mathrm{SEM}, n=19$ ), whereas this ratio ranged from 343 to $>5000$ in CPS I deficient livers and from $<0.02$ to 1.55 in OTC deficient livers. The OTC/CPS I ratio was found to be a reliable parameter for assessing enzymatic deficiency compensating for the observed variability of enzymatic activity between individual samples. OTC/CPS I ratio also seemed to correlate with the severity of disease in enzyme deficient patients. OTC-deficient patients with the highest residual enzymatic activity (1-3\% of normal) had a better outcome. These sensitive methods would help to establish the diagnosis of CPS I or OTC deficiency whenever only a very small amount of liver tissue is available and their results could be interpreted even if secondary reduction in the activities of these enzymes occurred due to collection or storage artifacts. Levels of
\end{abstract}

Received January 20, 1989; accepted March 27, 1989. Reprint requests Mende Tuchman M.D., Department of Pediatrics, University of Minnesota. Box 400 Mayo Memorial Building, 420 Delaware Street S.E., Minneapolis MN 55455.

Supported in part by Grants NO1-DK-6-2274 and HD 11134 from the Nationa Institutes of Health and by grants from the Minnesota Medical Foundation, the TA \& MA O'Malley Foundation and the Kettering Family Foundation. residual enzymatic activities may help to predict the prognosis of these patients. (Pediatr Res 26: 77-82, 1989)

\section{Abbreviations}

CPS I, carbamyl phosphate synthetase I

OTC, ornithine transcarbamylase

RFM, radioactivity flow monitoring

CPS I and OTC are two mitochondrial enzymes catalyzing the incorporation of ammonia into carbamyl phosphate (CPS I) and subsequently into L-citrulline (OTC) (1). Ammonium cation, ATP and bicarbonate anion are substrates for CPS I, an Nacetylglutamate-dependent enzyme catalyzing the formation of carbamyl phosphate according to the following stoichiometry:

$$
2 \mathrm{ATP}+\mathrm{HCO}_{3}^{-}+\mathrm{NH}_{4} \underset{\mathrm{H}_{3} \mathrm{PO}_{4}}{2} \mathrm{ADP}+\mathrm{H}_{2} \mathrm{NCOO} \mathrm{PO}_{3}^{--}+
$$

A similar enzyme (CPS II) is found in the cytosol, uses glutamine rather than ammonia as the amine donor, is not dependent on $\mathrm{N}$-acetylglutamate and catalyzes the first step of de novo pyrimidine synthesis. CPS I has been purified from livers of animals and humans and has been characterized $(2,3)$. Carbamyl phosphate formed in the CPS I catalyzed reaction subsequently reacts with the 6-amino group of ornithine to form citrulline in a reaction catalyzed by OTC:

$$
\text { carbamyl phosphate }+ \text { ornithine } \rightarrow \text { citrulline }+P_{i}
$$

Despite the CPS protein composing about $20 \%$ of the total protein content in the mitochondrial matrix (4), the specific activity of liver OTC in vitro is more than 20 -fold higher than that of CPS I (5). OTC has been purified to homogeneity from various sources $(6,7)$.

Deficiency of hepatic CPS I or OTC activity causes hyperammonemia which may lead in severe cases to coma and subsequent death or mental retardation $(8,9)$. The clinical diagnosis of CPS I deficiency in a hyperammonemic patient is suggested by low or absent plasma citrulline without orotic aciduria, whereas the presence of orotic aciduria suggests OTC deficiency. The definitive diagnosis, however, can be currently established only by enzymatic assays. Most currently available assays for both enzymes use indirect spectrophotometric estimation of citrulline $(10,11)$. When CPS I is assayed, the reaction is coupled to that of OTC and citrulline concentration is estimated as the final 
product. The spectrophotometric methods have several disadvantages. These are not sensitive enough to measure accurately low residual enzymatic activity. Moreover, the low sensitivity of these assays is limiting with respect to the minimal amount of tissue that is adequate for analysis and does not permit investigation of the enzymatic activities in tissues that have lower activities than liver for diagnosis or prenatal diagnosis of the enzymatic defects. Artifacts can potentially occur when using the spectrophotometric methods because citrulline is not directly measured which may potentially affect the specificity of the method. This study was undertaken to develop more sensitive and specific methods for the measurement of CPS I and OTC activities and to determine residual enzymatic activities in liver tissue of deficient patients. The methods use radioactive ornithine, separation of citrulline and ornithine by HPLC and quantitation of the radioactive citrulline by RFM.

\section{MATERIALS AND METHODS}

Materials. Ammonium bicarbonate, sodium bicarbonate, Lornithine, L-citrulline, ATP, N-acetylglutamate, and carbamyl phosphate and purified Streptococcus faecalis OTC were purchased from Sigma Chemical Co. St. Louis, MO. $\left[{ }^{14} \mathrm{C}\right]$ sodium bicarbonate $(55 \mathrm{mCi} / \mathrm{mmol})$ was purchased from Research Products International Corp. Mount Prospect, IL, L- $\left[1-{ }^{14} \mathrm{C}\right]$ ornithine $51.6 \mathrm{mCi} / \mathrm{mmol}$ from Du Pont/NEN Products, Boston, MA and L-[carbamyl- ${ }^{14} \mathrm{C}$ ]citrulline $(57.7 \mathrm{mCi} / \mathrm{mmol})$ from Amersham Corp., Arlington Heights, IL.

Liver Tissue. Frozen normal human liver tissue used in this study was obtained through the University of Minnesota "Liver tissue procurement and distribution system" by NIH contract. The livers were frozen shortly after harvesting in liquid nitrogen or were maintained for less than eight hours in a buffered solution (Wisconsin solution), after which sections of the liver were flash frozen in liquid nitrogen and stored at $-80^{\circ} \mathrm{C}$ from 3 days to 3 y until analysis. Liver tissue samples from patients with inherited deficiencies in the activities of CPS I or OTC were obtained surgically or immediately after death, frozen in liquid nitrogen and stored at $-80^{\circ} \mathrm{C}$ at the University of Minnesota or the Johns Hopkins Hospital. Storage time until analysis ranged from $1 \mathrm{~d}$ to $3 \mathrm{y}$. Eighteen of the patients studied were previously diagnosed enzymatically using spectrophotometric assays, however, their precise residual enzymatic activity was unknown. The other six patients were newly diagnosed by the assays described here. The specific diagnoses of all patients were unknown to the persons who developed and performed the assays until the conclusion of the study.

Preparation of Liver Homogenate. Sections of frozen liver were weighed and homogenized in $0.075 \mathrm{M} \mathrm{KCl}$ aqueous solution on ice by a Polytron apparatus using two 20 -s cycles with a 60 -s interval. The initial dilution of the homogenate $(10 \% \mathrm{w} / \mathrm{v})$ was used to assay CPS I. For assays of OTC, further 10-fold dilution $(1 \% \mathrm{w} / \mathrm{v})$ was performed. The tissue was homogenized less than $30 \mathrm{~min}$ before incubation and the enzymes in the homogenate were stable for several hours when kept at $0-4^{\circ} \mathrm{C}$.

Enzyme Assays. CPS I. The reaction was performed in a 2-ml tightly capped glass vial and the reaction mixture contained: 75 $\mathrm{mM}$ ammonium bicarbonate, $20 \mathrm{mM}$ ATP, $40 \mathrm{mM} \mathrm{MgCl}_{2}, 5$ $\mathrm{mM}$ N-acetylglutamate, $5 \mathrm{mM} \mathrm{L}-\left[1-{ }^{14} \mathrm{C}\right]$ ornithine $(5 \mu \mathrm{Ci} / \mathrm{ml}), 5$ $\mathrm{U} / \mathrm{ml}$ of purified OTC enzyme and $50 \mu \mathrm{l}$ of $10 \%$ liver homogenate (5 mg of tissue/assay), all dissolved in $500 \mu 150 \mathrm{mM}$ HEPES buffer, $\mathrm{pH}$ 7.3. Control reaction mixtures were identical except for containing liver homogenate previously boiled for $1 \mathrm{~min}$. The reaction was started by addition of liver homogenate and after incubation for $15 \mathrm{~min}$ at $37^{\circ} \mathrm{C}$ it was terminated by addition of $40 \mu \mathrm{l}$ of $30 \%$ trichloroacetic acid. The precipitated protein was removed by centrifugation, the reaction mixture supernatant was filtered through a $0.2-\mu \mathrm{m}$ filter and a $25-\mu \mathrm{l}$ aliquot was injected into the HPLC.

OTC. The reaction mixture contained $5 \mathrm{mM}$ carbamyl phos- phate, $5 \mathrm{mM} \mathrm{L}-\left[1-{ }^{14} \mathrm{C}\right]$ ornithine $(5 \mu \mathrm{Ci} / \mathrm{ml})$, and $50 \mu \mathrm{l}$ of $1 \%$ liver homogenate $(0.5 \mathrm{mg}$ of tissue/assay) dissolved in $500 \mu 170$ mM HEPES buffer $\mathrm{pH}$ 7.3. The incubation was terminated after 5 min. All other conditions of the reaction were identical to those of the CPS I assay.

Radiochromatographic separation and quantitation. L-citrulline formed during the CPS I and OTC reactions was separated from L-ornithine by HPLC (1090 liquid chromatograph, Hewlett Packard, Avondale, PA) using a $15-\mathrm{cm}$ long, 5- $\mu \mathrm{m}$ particle size, 4,6-ID $\mathrm{NH}_{2}$ column (Econosphere $\mathrm{NH}_{2}$, Alltech Associates, Deerfield, IL). A binary solvent system was used consisting of acetonitrile $/ \mathrm{H}_{2} \mathrm{O} 500 / 70 \mathrm{v} / \mathrm{v}$ (solvent $\mathrm{A}$ ) and $0.02 \mathrm{M}$ Na-phosphate in water, pH 4.2 (solvent $\mathrm{B}$ ). The solvent program was 1 ) 0 min, $95 \%$ solvent $A, 5 \%$ solvent $B$; 2) 0-15 min, linear gradient up to $50 \%$ solvent A, 50\% solvent B; 3) 15-25 min linear gradient up to $30 \%$ solvent A, $70 \%$ solvent B. Column temperature was $40^{\circ} \mathrm{C}$, flow rate $1 \mathrm{ml} / \mathrm{min}$. Detection of the "cold" standards was by UV absorption at $205 \mathrm{~nm}$ wave length. Radioactive peaks of $\left[{ }^{14} \mathrm{C}\right]$ labeled compounds were detected and quantitated by the radioactivity flow monitor (Radiomatic Instruments Co., Tampa, FL) connected to the HPLC outflow, employing a 250 $\mu \mathrm{l}$ flow-cell and scintillation fluid/eluate ratio of $4 / 1$. The reaction product, $\mathrm{L}-\left[1-{ }^{14} \mathrm{C}\right]$ citrulline was separated from $\left[1-{ }^{14} \mathrm{C}\right]$ ornithine and their radioactivity was quantitated. The specific enzymatic activities were calculated from the amount of labeled citrulline generated from labeled ornithine during the reactions and were expressed in $\mu \mathrm{mol} / \mathrm{g}$ tissue $/ \mathrm{min}$. The mean counting efficiency of the RFM for $\left[{ }^{14} \mathrm{C}\right]$ was about $90 \%$. Using a $250-\mu 1$ counting cell and a scintillation fluid/eluate ratio of 4.0 , the SD of the counts observed in the citrulline peak on repeated injections of normal samples was less than $\pm 2 \%$. In samples with low residual enzymatic activities the citrulline peak was also collected and counted in a scintillation counter for $2 \mathrm{~min}$.

The linearity of the citrulline amounts generated in CPS I and OTC reactions with respect to incubation time was determined as follows. Six identical CPS I assay preparations each containing $5 \mathrm{mg}$ of liver homogenate and another six OTC assay preparations each containing $0.5 \mathrm{mg}$ were stopped at $0,5,10,15,20$, and $25 \mathrm{~min}$ and the citrulline generated was determined as described above. To estimate the linearity and sensitivity of these assays, enzymatic activity was determined for a range of 1 to 5 $\mathrm{mg}$ of tissue/assay for CPS I incubated for $15 \mathrm{~min}$ and 0.1 to 0.5 $\mathrm{mg} /$ assay for OTC incubated for $5 \mathrm{~min}$.

To study the reproducibility of the radiochromatographic method at low enzyme activity levels, two groups of five identical OTC assays of liver tissue of one patient with OTC deficiency were tested. Assay mixtures of one group contained $5 \mathrm{mg}$ of liver tissue each ( $1 \%$ dilution of liver homogenate), whereas those of the second group contained $0.5 \mathrm{mg}(0.1 \%$ dilution of liver homogenate).

These studies have been reviewed and approved by the Institutional Review Board On The Use of Human Subjects In Research at the University of Minnesota.

\section{RESULTS}

The HPLC-RFM system used in this study separated efficiently L-ornithine from L-citrulline with 8-min difference in the retention times between the two peaks (Fig. 1).

Initially we have attempted to use $\left[{ }^{14} \mathrm{C}\right]$ sodium bicarbonate as the labelled substrate for CPS I, however, we obtained low and variable counts in the citrulline due to spontaneous decomposition of labeled bicarbonate to $\mathrm{CO}_{2}$ which amounted to $50 \%$ or more in $20 \mathrm{~min}$ at $37^{\circ} \mathrm{C}$. This disappearance of radioactivity was not prevented by the addition of $50 \mu \mathrm{M}$ acetazolamide (carbonic anhydrase inhibitor) and occurred also in control samples. Use of $\mathrm{L}-\left[1-{ }^{14} \mathrm{C}\right]$ ornithine instead resulted in reproducible and much higher citrulline counts.

Termination of the enzymatic reactions by boiling was initially attempted but in the controls of the OTC reaction, it resulted in 


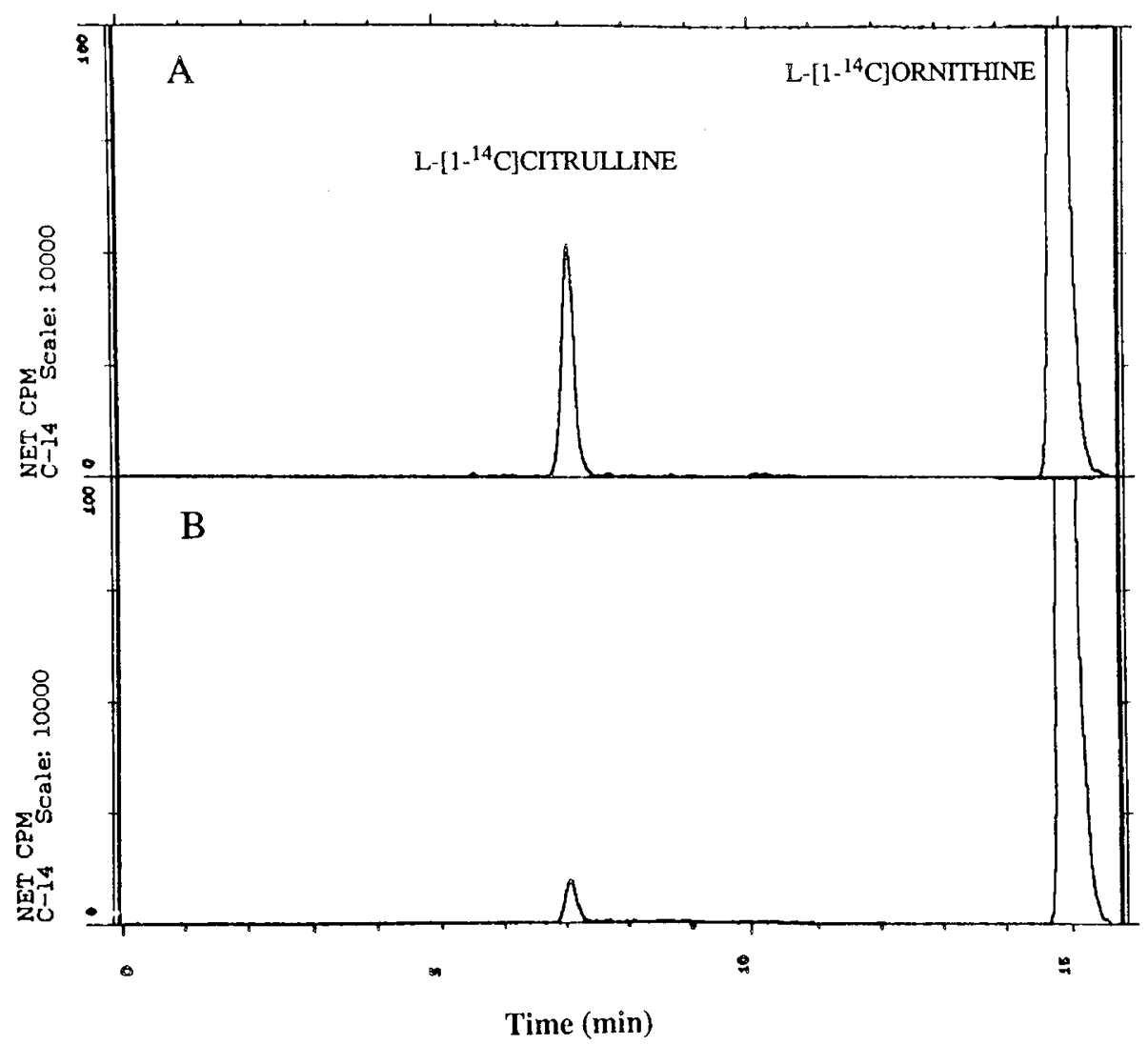

Fig. 1. $\left[{ }^{14} \mathrm{C}\right]$ radioactivity chromatograms obtained from OTC reaction mixtures containing liver homogenates of normal $(A)$ and of an OTCdeficient individual $(B)$. To obtain a visible citrulline peak, liver tissues of the OTC-deficient patient was assayed using $5 \mathrm{mg}$ of tissue and $15 \mathrm{~min}$ incubation (30-fold increased sensitivity compared to the OTC assay of normal liver where only $0.5 \mathrm{mg}$ of liver and 5-min incubation was used). The enzymatic activity of the normal OTC liver $(A)$ was $135.8 \mu \mathrm{mol} / \mathrm{g} / \mathrm{min}$ and that of the deficient liver $(B) 0.74 \mu \mathrm{mol} / \mathrm{g} / \mathrm{min}$.

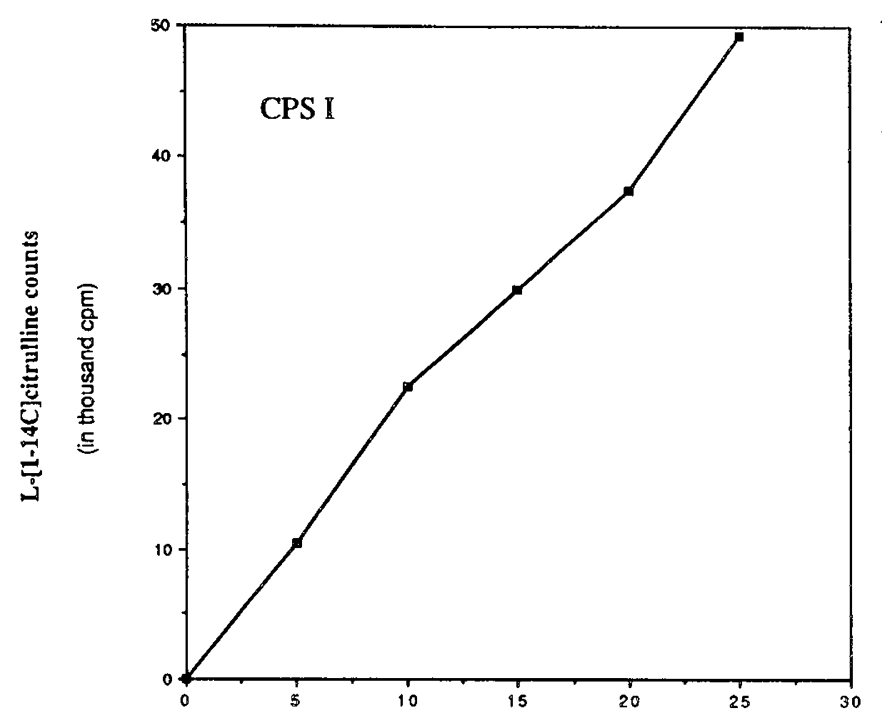

Time (min)

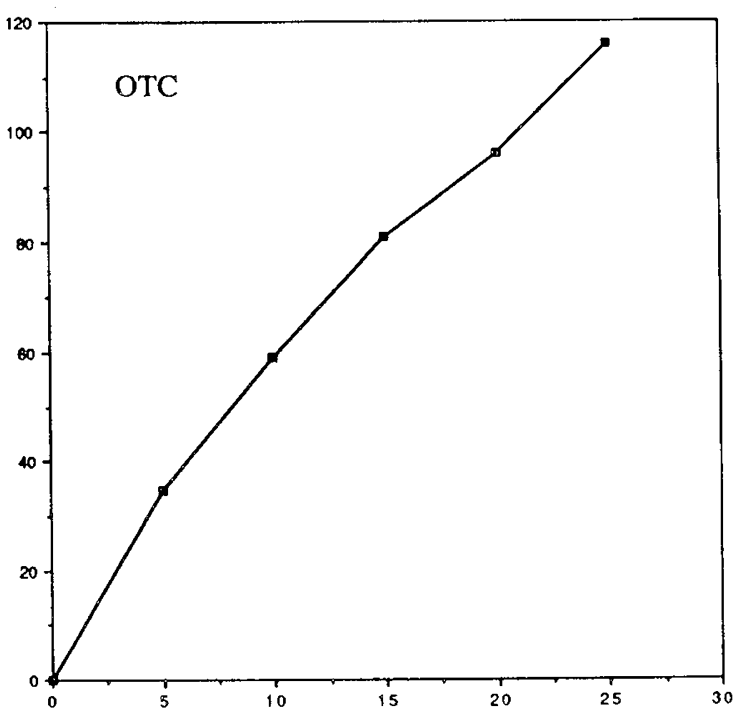

Time (min)

Fig. 2. Effect of length of incubation time on generation of $L-\left[1-{ }^{14} \mathrm{C}\right]$ citrulline from $L-\left[1-{ }^{14} \mathrm{C}\right]$ ornithine during CPS I and OTC reactions as determined by the radiochromatographic method. Five mg of tissue per assay was used for CPS I and $0.5 \mathrm{mg}$ for OTC, other conditions were as described in "Materials and Methods."

significant nonenzymatic generation of citrulline (up to $20 \%$ of enzymatic activity). Minimal chemical production of citrulline (less than $0.2 \%$ of substrate conversion) occurred when trichloroacetic acid was used to terminate the reaction and precipitate the protein; it was therefore used to stop both the CPS I and OTC reactions.

Figure 2 shows plots of the time dependent citrulline radioactivity obtained during CPS I and OTC assays of normal human 
liver. Both reactions appear relatively linear with time. The highest specific activity for OTC $145.8 \mu \mathrm{mol} / \mathrm{g} / \mathrm{min}$ was in the first $5 \mathrm{~min}$ of incubation falling to $98.0 \mu \mathrm{mol} / \mathrm{g} / \mathrm{min}$ by $25 \mathrm{~min}$ of incubation. However, the sp act of CPS I was similar up to 15 min of incubation, $4.45 \pm 0.22$ (mean $\pm \mathrm{SEM}) \mu \mathrm{mol} / \mathrm{g} / \mathrm{min}$ falling slightly to $3.75 \mu \mathrm{mol} / \mathrm{g} / \mathrm{min}$ between 15 and $25 \mathrm{~min}$.

Figure 3 shows that increments in the concentrations of liver tissue homogenates resulted in a linear increase of citrulline radioactivity generated during CPS I and OTC assays. The sensitivity of this method can be estimated from the citrulline counts of the above experiment. Assuming linearity of citrulline counts, CPS I activity should be easily measurable using only 0.5 $\mathrm{mg}$ of liver tissue with normal enzymatic activity and assays for OTC activity may be performed on as little as $0.05 \mathrm{mg}$ of tissue. Activity as low as $0.1 \mu \mathrm{mol} / \mathrm{g} / \mathrm{min}$ for CPS I and OTC could be reliably measured in $5 \mathrm{mg}$ of enzyme deficient liver.

The reproducibility of the radiochromatographic assays system was examined on liver tissue of one OTC-deficient patient using five identical assay mixtures containing $5 \mathrm{mg}$ of tissue each and another five mixtures containing $0.5 \mathrm{mg}$ of tissue each. The results obtained were $2.96 \pm 0.07 \mu \mathrm{mol} / \mathrm{g} / \mathrm{min}$ (mean $\pm \mathrm{SEM}, n$ $=5$ ) and $2.30 \pm 0.09 \mu \mathrm{mol} / \mathrm{g} / \mathrm{min}$ (mean $\pm \mathrm{SEM}, n=5$ ), respectively.

The enzymatic activity of CPS I and OTC of normal frozen liver tissue is shown in Table 1. CPS I activity in several different sections of four normal livers was $3.01 \pm 0.16 \mu \mathrm{mol} / \mathrm{g} / \mathrm{min}$ (mean \pm SEM, $n=19$ ) and OTC activity was $93.4 \pm 6.3$ (mean \pm SEM, $n=19$ ). OTC/CPS I activity ratio was $31.2 \pm 1.3$ (mean \pm SEM, $n=19$ ) and seemed to have a lower degree of variability than either enzymatic activity. Moreover, despite low enzymatic activities in the cirrhotic liver the OTC/CPS I ratio remained within the normal range. Normal liver 4 was stored for $3 \mathrm{y}$, yet it still had high enzymatic activities. This liver was removed from a brain dead patient whose kidneys were donated for transplantation and his vascular perfusion was optimal until the liver was harvested and immediately frozen in liquid nitrogen. Liver 3 was stored for close to 100 days until analysis and also had high enzymatic activities. It was immersed in cold buffered solution immediately after harvest and maintained in that solution for $8 \mathrm{~h}$ until deep freezing. However, livers 1 and 2 were not frozen immediately after harvest and despite shorter storage time, their enzymatic activities were the lowest. Liver 2 also showed marked variability of enzymatic activity between the different sections which may be explained by variable degree of segmental necrosis.

The enzymatic deficiency established by the radiochromatographic CPS I and OTC assays proved to be identical to the previously known diagnosis in all patients with enzyme defects in whom a diagnosis was previously made. The OTC/CPS I ratio proved to be a reliable parameter for establishing the correct diagnosis. For example, samples from patients 7, 15, and 16 (Table 3) were initially assessed to be inadequate for analysis due

Table 1. OTC and CPS I activity in frozen sections of normal liver and of cirrhotic liver*

\begin{tabular}{crrcc}
\hline Normal liver (no.) $\dagger$ & OTC & CPS I & OTC/CPS I & Storage timef \\
\hline 1 & 81.1 & 2.50 & 32.4 & 3 \\
1 & 69.0 & 2.00 & 34.5 & 3 \\
1 & 65.3 & 2.30 & 28.4 & 3 \\
2 & 90.6 & 3.10 & 29.2 & 43 \\
2 & 87.6 & 4.40 & 19.9 & 44 \\
2 & 145.8 & 4.10 & 35.6 & 45 \\
2 & 59.5 & 1.84 & 32.3 & 48 \\
2 & 56.5 & 2.30 & 24.6 & 50 \\
2 & 82.1 & 2.20 & 37.3 & 52 \\
2 & 77.7 & 2.83 & 27.5 & 55 \\
2 & 59.3 & 2.62 & 22.6 & 58 \\
3 & 152.0 & 3.72 & 40.9 & 93 \\
3 & 100.0 & 3.25 & 30.8 & 97 \\
3 & 102.0 & 3.60 & 28.3 & 119 \\
3 & 114.1 & 2.99 & 38.2 & 120 \\
4 & 117.4 & 3.70 & 31.7 & $3 \mathrm{y}$ \\
4 & 115.1 & 3.30 & 34.9 & $3 \mathrm{y}$ \\
4 & 110.2 & 3.10 & 35.5 & $3 \mathrm{y}$ \\
4 & 89.7 & 3.30 & 27.2 & $3 \mathrm{y}$ \\
Cirrhosis§ & 22.0 & 0.85 & 25.9 & $6 \mathrm{y}$ \\
\hline
\end{tabular}

* Expressed as $\mu \mathrm{mol} / \mathrm{g}$ tissue/min, mean of two to three assays.

$\dagger$ Separate sections taken from normal frozen liver tissue of four different individuals (nos. 1-4).

$\$$ Storage time at deep freezing from harvest until analysis in days except where indicated otherwise.

$\S$ Anti-trypsin deficiency.

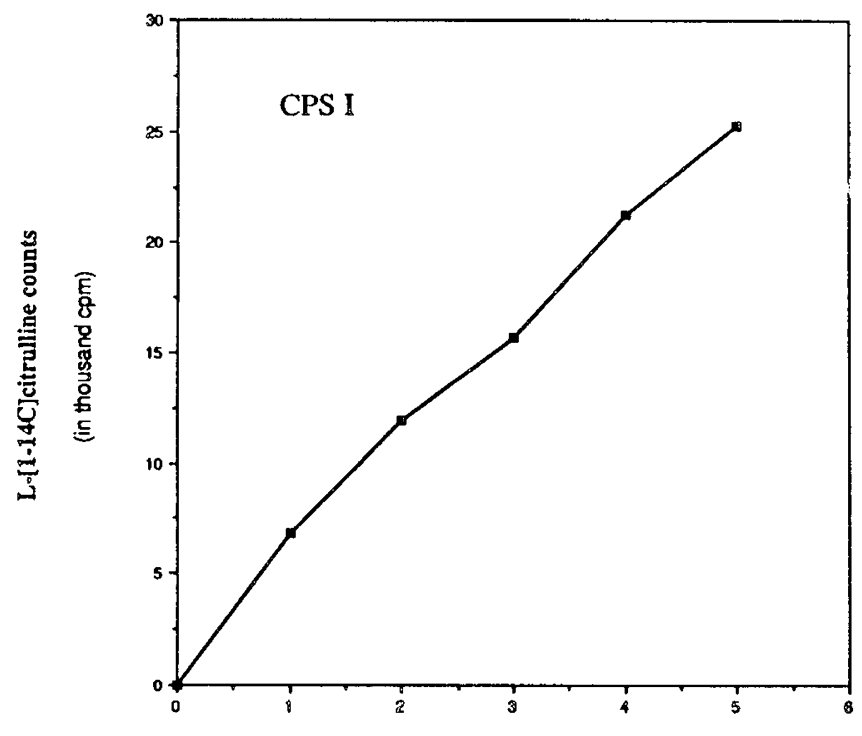

Amount of tissue (mg)

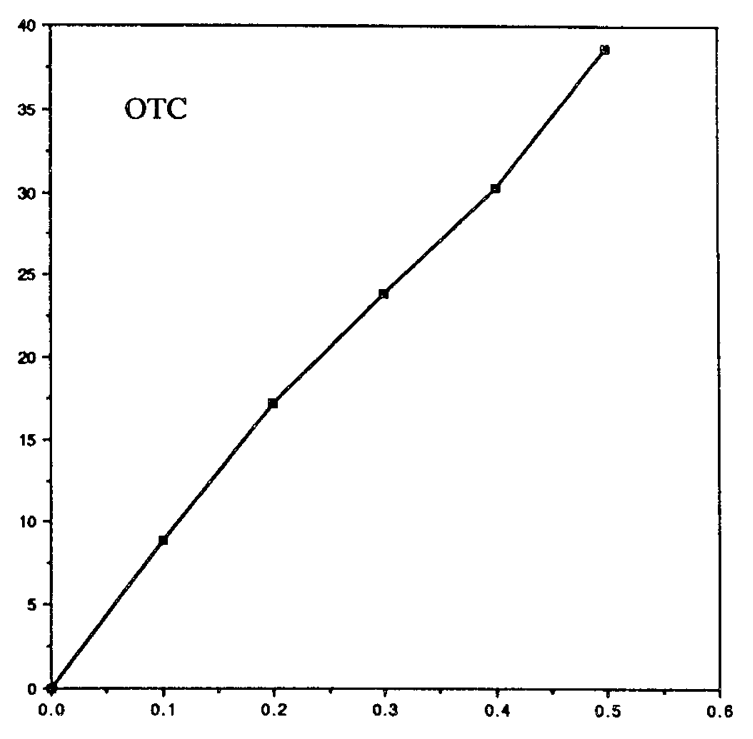

Amount of tissue (mg)

Fig. 3. Effect of tissue homogenate concentration $(\mathrm{mg} / 500 \mu \mathrm{l})$ on generation of $\mathrm{L}-\left[1-{ }^{14} \mathrm{C}\right]$ citrulline from L- $\left[1-{ }^{14} \mathrm{C}\right]$ ornithine during CPS I and OTC reactions as determined by the radiochromatographic method. The 15 - or 5 -min incubation time length was used for the CPS I and OTC assays, respectively, other assays conditions were as described in "Materials and Methods." 
to extremely low amounts of liver material or problems with homogenization, however, in spite of low enzymatic activities ( $10 \%$ or less of normal) of the unaffected enzyme (CPS I), the OTC/CPS I activity ratios clearly indicated OTC deficiency which proved to be the correct diagnosis of all three patients.

The enzymatic activities and outcome of patients with CPS I deficiency are summarized in Table 2 . Patient 4 was the only one with measurable residual enzymatic activity and the lowest OTC/CPS I activity ratio and survived on medical therapy alone. However, he was treated prospectively because of a history of a previously affected sibling. The only other patient that survived (no. 3) did poorly and orthotopic liver transplantation was performed as an alternative therapy. He had unmeasurable CPS I activity in his liver.

Table 3 summarizes the results of patients with OTC activity. Patient 1 had the highest residual enzymatic activity and the highest OTC/CPS I ratio. He did not have congenital hyperammonemia and his recurrent hyperammonemia episodes are relatively mild. Patient 2 has relatively high residual enzymatic activity and higher OTC/CPS I ratio than most other patients; also he did not have neonatal hyperammonemia. He presented with "Reye-like" disease and mild hyperammonemia at the age of $2 \mathrm{y}$ and is now alive and well. Patient 3 did not have neonatal hyperammonemia, he developed well until 4 mo of age when he presented in hyperammonemic coma, he was successfully treated and is alive. Patient 4 was apparently "healthy" until the age of $6 \mathrm{y}$ when he developed hyperammonemic coma and died. Patient 14 with relatively high OTC/CPS I ratio survived for $3 \mathrm{y}$, whereas most patients with ratios of less than 0.1 died in the neonatal period. The relatively high ratio in the liver of patient 15 may not be accurate due to artificially low enzymatic activities as indicated by low activity of the unaffected enzyme (CPS I).

\section{DISCUSSION}

The availability of highly sensitive and specific enzyme assays for CPS I and OTC is advantageous with respect to diagnosis and research of these hyperammonemic syndromes. The radiochromatographic assays for diagnosis of an enzyme deficiency would be reliable even with $0.5 \mathrm{mg}$ of tissue for CPS I and 0.05 $\mathrm{mg}$ for OTC. This high sensitivity enables diagnosis of these disorders in a newborn using one needle biopsy puncture. To reliably measure residual enzymatic activity as low as $0.1 \mu \mathrm{mol} /$ $\mathrm{g} / \mathrm{min}$, a minimum of $5 \mathrm{mg}$ of liver tissue is required. Liver tissue for residual enzyme activity measurement should be assayed as soon after harvest as possible to minimize denaturation of unstable enzyme protein.

Previously reported assays employing radioactive substrates which did not separate the radioactive product, relied on the complete elimination of the substrate radioactivity by acidification and boiling before determining the residual radioactivity assumed to be in the reaction product, citrulline or its derivative hydroxyurea (11-13). These methods have two main shortcomings: first, errors can occur when elimination of the radioactive substrates is not complete (e.g. when using higher specific radioactivity to improve sensitivity) and second, unstable radioactive substrates such as bicarbonate or carbamyl phosphate have been used which may degrade spontaneously during incubation (14).

Table 2. OTC and CPS I activity in frozen sections of livers of patients with CPS I deficiency*

\begin{tabular}{crrccll}
\hline Patient $\dagger$ & OTC & CPS I & OTC/CPS & Neonatal coma & Hyperammonemia & Outcome \\
\hline 1 & 29.5 & $<0.01$ & $>2500$ & Yes & Severe & Dead at $4 \mathrm{~d}$ \\
2 & 64.6 & $<0.01$ & $>5000$ & Yes & Severe & Dead at 2 wk \\
3 & 137.7 & $<0.01$ & $>5000$ & Yes & Severe, Tx $¥$ at 14 mo & Mental retardation \\
4 & 41.1 & 0.12 & 343 & Prospectively treated & & Alive and well \\
5 & 60.3 & $<0.01$ & $>5000$ & Yes & Severe & Dead at 3d \\
\hline
\end{tabular}

* Expressed as $\mu \mathrm{mol} / \mathrm{g}$ tissue/min.

$\dagger$ Patients with inherited defects in CPS I, samples obtained from the University of Minnesota and John Hopkins Medical Center.

+ Liver transplantation.

$\S$ Treated prospectively at birth.

Table 3. OTC and CPS I activity in frozen sections of livers of patients with OTC deficiency*

\begin{tabular}{|c|c|c|c|c|c|c|}
\hline Patient $\dagger$ & OTC & CPS I & OTC/CPS & Neonatal coma & Hyperammonemia & Outcome \\
\hline 1 & 2.52 & 1.63 & 1.55 & No & Mild & Mental retardation \\
\hline 2 & 2.40 & 3.50 & 0.69 & No & Mild & Reye syndrome, normal \\
\hline 3 & 1.1 & 2.70 & 0.41 & No & Severe, $4.5 \mathrm{mo}$ & Alive \\
\hline 4 & 0.74 & 5.04 & 0.15 & No & Mild & Dead at $6 \mathrm{y}$ \\
\hline 5 & $<0.05$ & 3.23 & $<0.02$ & Yes & Severe & Dead at $2 \mathrm{~d}$ \\
\hline 6 & 0.26 & 4.13 & 0.06 & & Prospectively treated $\ddagger$ & $\mathrm{Tx} \S$ at $22 \mathrm{mo}$ \\
\hline 7 & $<0.05$ & 0.57 & $<0.08$ & Yes & Severe & Dead at $23 \mathrm{~d}$ \\
\hline 8 & 0.36 & 4.53 & 0.08 & Yes & Severe & Dead at $4 \mathrm{~d}$ \\
\hline 9 & 0.14 & 2.71 & 0.05 & & 2 nd trimester abortus & \\
\hline 10 & 0.10 & 3.03 & 0.03 & Yes & Severe & Dead at $4 \mathrm{~d}$ \\
\hline 11 & $<0.05$ & 3.44 & $<0.02$ & Yes & Severe & Dead at $9 \mathrm{~d}$ \\
\hline 12 & 0.28 & 2.01 & 0.14 & Yes & Severe & Dead \\
\hline 13 & 0.07 & 2.61 & 0.03 & Yes & Severe & Dead \\
\hline 14 & 0.56 & 2.80 & 0.20 & Yes & Severe & Dead at $3 y$ \\
\hline 15 & 0.56 & 0.55 & 1.02 & Yes & Severe & Dead at $23 \mathrm{~d}$ \\
\hline 16 & $<0.05$ & 0.18 & $<0.28$ & Yes & Severe & Dead at 2 y \\
\hline 17 & 0.11 & 2.90 & 0.04 & & Prospectively treated, Tx§ at $18 \mathrm{mo}$ & Alive and well \\
\hline 18 & $<0.05$ & 3.60 & $<0.02$ & Yes & Severe & Dead, $10 \mathrm{~d}$ \\
\hline 19 & 0.12 & 3.00 & 0.04 & Yes & Severe & Dead, $7 \mathrm{~d}$ \\
\hline
\end{tabular}

* Expressed as $\mu \mathrm{mol} / \mathrm{g}$ tissue $/ \mathrm{min}$.

$\dagger$ Patients with inherited defects in OTC, samples obtained from the University of Minnesota and John Hopkins Medical Center.

$\ddagger$ Treated since birth due to previously affected sibling.

$\S$ Liver transplantation. 
Labeled ornithine has been used before to assay OTC activity but the separation of substrate and product was performed by thin-layer chromatography (15). The methods described herein avoid these disadvantages by using radiolabeled ornithine and measuring citrulline radiometrically after chromatographic separation. These sensitive methods are also highly reproducible at low enzyme activity levels and can therefore be used to measure residual enzymatic activity which may prove to be a useful parameter for prediction of prognosis. It is feasible that the separation of ornithine and citrulline by ion exchange could be achieved without HPLC using small gravity columns, however we have not attempted to study this approach.

High enzymatic activity for both CPS I and OTC was observed in a normal liver stored for $3 \mathrm{y}$. However, lower enzymatic activities were found in liver tissue stored for much shorter times. We conclude from our results of normal liver tissue that length of storage may not be the most important factor determining enzyme stability but rather the method of harvesting or the condition of the liver when harvested may be more important in this regard. The range of OTC/CPS I ratios in normal liver tissue have been determined to enable use of the non-deficient enzyme activity as an internal control. As shown in our results, despite low CPS I and OTC activities in a liver with severe cirrhosis, their activity ratio remained normal. This may indicate that similar proportions of CPS I and OTC activities occur in such conditions. Thus, the OTC/CPS I ratio would be particularly useful for the diagnosis of CPS I and OTC deficiency when secondary loss of enzymatic activities occurs due to tissue necrosis or inadequate sample collection.

The results obtained from the analysis of enzyme-deficient liver tissues showed that the OTC/CPS I ratio was diagnostic in each tissue sample examined. Although there seems to be an inverse correlation between residual enzymatic activities and outcome, these patients were not treated uniformly at the various medical facilities, a fact that could significantly affect their outcome. However, none of the four OTC-deficient patients with residual OTC activity between 1 and $3 \%$ of normal has had neonatal hyperammonemia and their outcome was generally better than the other patients. Based on these results, we postulate that patients with residual OTC activity levels as low as $1-3 \%$ of normal may have a better prognosis than patients with a complete enzyme deficiency. It is also possible, however, that some mutant enzymes are unstable and rapidly lose their activities during storage or during incubation of the assay mixtures, resulting in the underestimation of their in vivo enzymatic activities.

CPS I and OTC activities are expressed also in the intestinal mucosa $(16,17)$, however, their expression in other tissues is controversial. Some authors have suggested the presence of en- zymatic activity in leukocytes, however, this was refuted by others (18-20). The method described herein could prove useful to resolve the controversy regarding expression of CPS I and OCT in easily obtainable tissue as well as for investigating the presence of their activity in chorionic villus for the purpose of prenatal diagnosis.

\section{REFERENCES}

1. Ratner S 1973 Enzymes of arginine and urea synthesis. Adv Enzymol 39:1-90

2. Marshall M, Metzenberg RL, Cohen PP 1961 Physical and kinetic properties of carbamyl phosphate synthetase from frog liver. J Biol Chem 236:2229 2237

3. Pierson DL, Brien JM 1980 Human carbamyl phosphate synthetase I. Stabilization, purification and partial characterization of the enzyme from human liver. J Biol Chem 255:7891-7895

4. Clarke S 1976 A major polypeptide component of rat liver mitochondria: carbamyl phosphate synthetase. J Biol Chem 251:950-961

5. Jackson MJ, Beaudet AL, O'Brien WE 1986 Mammalian urea cycle enzymes. Annu Rev Genet 20:431-464

6. Kalonsek F, Francois B, Rosenberg LE 1978 Isolation and characterization of ornithine transcarbamylase from normal human liver. J Biol Chem 253:3939-3944

7. Lusty CJ, Jilka RL, Nietsch EH 1979 Ornithine transcarbamylase of rat liver. J Biol Chem 254:10030-10036

8. Gelehrter TD, Snodgrass PJ 1974 Lethal neonatal deficiency of carbamyl phosphate synthetase. N Engl J Med 290:430-433

9. Campbell AGM, Rosenberg LE, Snodgrass PJ, Nuzum CT 1973 Ornithine transcarbamylase deficiency. A course of lethal neonatal hyperammonemia in males. N Engl J Med 288:1-6

10. Archibald RM 1944 Determination of citrulline and allantoin and demonstration of citrulline in blood plasma. J Biol Chem 156:121-142

11. Levine RI, Kretchmer H 1971 Conversion of carbamyl phosphate to hydroxyurea. An assay for carbamyl phosphate synthetase. Anal Biochem 42:324337

12. Goldstein AS, Hoogenraad NJ, Johnson JD, Fukanaga K, Swierczewski E, Cann HM, Sunshine P 1974 Metabolic and genetic studies of a family with ornithine transcarbamylase deficiency. Pediatr Res 8:5-12

13. Holzgreve W, Golbus MS 1984 Prenatal diagnosis of ornithine transcarbamylase deficiency utilizing fetal liver biopsy. Am J Hum Genet 36:320-328

14. Allen CM, Jones ME 1964 Decomposition of carbamyl phosphate in aqueous solutions. Biochemistry 3:1238-1247

15. McLaren J, Ng WG 1977 Assay of ornithine carbamoyltransferase activity in human liver using carbon-labeled ornithine and thin-layer chromatography. Clin Chim Acta 81:193-201

16. Hoogenraad NJ, Mitchell JD, Don NA, Sutherland TM, McLeay AC 1980 Detection of carbamyl phosphate synthetase I deficiency using duodenal biopsy samples. Arch Dis Child 55:292-295

17. Matsushima A, Orii T 1981 The activity of carbamyl phosphate synthetase I (CPS I) and ornithine transcarbamylase (OTC) in the intestine and the screening of OTC deficiency in the rectal mucosa. J Inherited Metab Dis 4:83-84

18. Wolfe DM, Gatefield PD 1975 Leukocyte urea cycle enzymes in hyperammonemia. Pediatr Res 9:531-535

19. Nagata N, Akaboshi I, Yamamoto J, Matsuda I, Ohtsuka H, Katsuki $\Upsilon 1980$ Ornithine transcarbamylase (OTC) in white blood cells. Pediatr Res 14:13701373

20. Snodgrass PJ, Wappner RS, Brandt IK 1978 White cell ornithine transcarbamylase activity cannot detect the liver enzyme deficiency. Pediatr Res 12:873 